\title{
Erratum to: Determination of Pomological and Morphological Characteristics with Fatty Acid Composition of High Kernel Ratio Walnut Genotypes
}

Hülya Ünver · Ebru Sakar • Melekber Sülüşoğlu

Published online: 15 December 2015

(C) Springer-Verlag Berlin Heidelberg 2015

\section{Erratum to:}

Erwerbs-Obstbau

DOI 10.1007/s10341-015-0249-3

The positions of the English and German titles were reversed in the original publication but the error has since been corrected.
The publisher apologises for this mistake and the inconvenience caused.

The online version of the original article can be found under doi:10.1007/s10341-015-0249-3

H. Ünver $(\bowtie)$

Kalecik Vocational School, Ankara univ,

06870 Kalecik, Ankara, Turkey

e-mail: hulyaunver@hotmail.com

E. Sakar

Faculty of Agriculture, Department of Horticulture, Harran univ,

63100 Şanlıurfa, Turkey

M. Sülüşoğlu

Arslanbey Vocational School, Kocaeli Univ,

41285 Kocaeli, Turkey 